Reprod. Nutr. Dévelop., 1980, 20 (4 B), 1351-1359.

\title{
Effect of fermentable carbohydrates on volatile fatty acids, ammonia and mineral absorption in the rat caecum
}

\author{
par C. DEMIGNÉ, C. RÉMÉSY, Y. RAYSSIGUIER \\ Laborafoire des Maladies métaboliques, I. N. R. A. \\ Theix 63110 Beaumont, France
}

\begin{abstract}
Summary. The effects of poorly digested carbohydrates in the small intestine on caecal digestion and absorption have been studied in the rat. Even in diets lacking these carbohydrates, there was a noticeable production of volatile fatty acids (VFA) in the caecum. Except for cellulose, the carbohydrates (bran, pectin, guar-gum, crude potato-starch, lactose, lactulose) favoured considerable development of the caecum and enhanced the quantities of VFA present there. On reaching the caecum, they increased ammonia absorption as a result of a higher uptake of blood urea, even if a greater part of the urea nitrogen was used in bacterial protein synthesis. Arteriovenous differences in the caecum showed a considerable absorption of various electrolytes. VFA absorption seemed to be accompanied by a release of $\mathrm{Cl}^{-}$into the caecal contents and by absorption of the main cations, $\mathrm{Na}^{+}$ being absorbed along an unfavourable gradient between the plasma and the caecal contents.
\end{abstract}

\section{Introduction.}

The production of volatile fatty acids (VFA) in the caecum of the rat has been described in previous studies (Yang, Manoharan and Mickelsen, 1970 ; Rémésy and Demigné, 1976). This phenomenon is essentially associated with the digestion of carbohydrates, for which hydrolysing enzymes are lacking or poorly efficient in the small intestine.

These carbohydrates are mainly cell-wall polysaccharides (cellulose, hemicelluloses, pectins) or related compounds such as gums (Bailey, Chesson and Monro, 1978). The role of these dietary fibers has gained widespread interest recently in studies on human nutrition (Trowell, 1978).

The concept of dietary fiber must be extended to other carbohydrates resisting digestion by intestinal enzymes ( $\alpha$-galactosides, lactulose) or partially hydrolysed in the small intestine (uncooked potato-starch, lactose in some species).

In addition to VFA production, urea is transferred from the blood to the digestive contents, particularly in the large bowel, and ammonia is absorbed (Vince et al., 1973 ; Knutson ef al., 1977). The effect of carbohydrates reaching the large bowel has been studied with lactulose mainly in humans (Vince, Killingley and Wrong, 1978) and with lactose in rats (Demigné and Rémésy, 1979). The effect of other carbohy- 
drates frequently encountered in dietary fibers on these processes is obviously interesting.

In addition, while VFA absorption is a well-known process in all species (Argenzio, Miller and Von Engelhardt, 1975 ; McNeil, Cummings and James, 1978), the consequences on water and mineral absorption are still poorly documented.

The present paper describes the role of caecal fermentation with various carbohydrates on nitrogen cycling and on volatile fatty acid and electrolyte absorption in the rat.

\section{Material and methods.}

Animals and diets. - Male Sherman rats weighing 200 to $250 \mathrm{~g}$ and fed ad libifum were adapted to successive light/dark periods (lights out from 9 a.m. to 9 p.m.). The food was changed at $8: 30 \mathrm{a.m}$. ; samples of the blood and digestive contents were obtained between 3 p.m. and 5 p.m. The control semi-purified diet contained percentages of the following : casein 15, corn oil 5, wheat-starch 74, salt mixture 5 and vitamin mixture 1. The percentages of carbohydrates studied were included at the expense of wheat-starch as follows : cellulose 15, commercial wheatbran 15, pectin 5, guar gum 5, lactulose 10, uncooked potato-starch 20 or codex lactose 20 . The levels used were practically the highest that could be given without causing a marked decline in the growth rate. The fraction available for fermentation in the large intestine was considered as 45 p. 100 for lactose (Kim, Benevenga and Grummer, 1978) and estimated in the same range for the uncooked potato-starch used in the present study. The salt and vitamin were supplied by UAR (Villemoisson s/Orge), pectin and guar gum by Sigma (St. Louis, USA), cellulose powder by Durieux (Paris), crude potato-starch by Tipiak (Nantes) and lactulose by Duphar. (Villeurbanne).

Experimental procedure. - Rats that had been fed one of the diets for 10 to 14 days were anesthetized with Nembutal $(40 \mathrm{mg} / \mathrm{kg}$ ). After about $20 \mathrm{~min}, 1 \mathrm{ml}$ of blood was taken from the caecal vein then from the aorta. The whole fresh weight of the caecal wall + contents was measured; aliquots of about $1 \mathrm{~g}$ were collected for measurement of $\mathrm{pH}$, dry matter, minerals, ammonia and organic acids. The caecal wall was then thoroughly washed with saline, blotted on filter paper and weighed; the true value of the caecal content weight was thus obtained by difference. Caecal vein-artery differences allow comparisons between the nef transfer of various metabolites or electrolytes. However, quantification of metabolite flux would require blood flow measurement ; nevertheless, it seems that caecal blood flow is relatively proportional to caecal development in conventional animals.

Metabolite determination. - Supernatants $(8000 \mathrm{~g}, 5 \mathrm{~min})$ of the caecal contents were treated by $0.4 \mathrm{M} \mathrm{HClO}_{4}(1 \mathrm{v} / 20 \mathrm{v})$; after centrifugation $(8000 \mathrm{~g}, 1 \mathrm{~min})$, the aliquots were used for enzymatic determination of ammonia and $D$ - or L-actic acid (Bergmeyer, 1974). Plasma ammonia and urea were determined without deproteinization (Beigmeyer, 1974). Volatile fatty acid measurement by glc has been previously described (Rémésy and Demigné, 1974, 1976). The chloride was determined on an Eppendorf 6610 Chloridmeter ; the plasma cations ( $\mathrm{Na}, \mathrm{K}, \mathrm{Ca}, \mathrm{Mg}$ ) were measured with a Perkin Elmer atomic absorption spectrophotometer, model 400. 


\section{Results.}

Change in caecal development and VFA concentrations (tables 1, 2). - Despite striking differences in caecal development with various substrates, the total VFA concentrations were in the same range; the caecal VFA pools, however, exhibited marked differences.

With the very digestible wheat-starch diet, VFA were probably produced from endogenous substrates (mucopolysaccharides, amino sugars, endogenous proteins) with a poorly developed caecum and a relatively high $\mathrm{pH}$. Cellulose was poorly utilized by the caecal flora, while bran produced noticeable caecal fermentation probably due to the hemicelluloses which are more readily fermentable than cellulose in the rat (Keys, Van Soest and Young, 1969). More than 5 p. 100 of pectin and guar gum could not be administered due to their high water-holding capacities. They favoured extensive caecal development but at a relatively high $\mathrm{pH}$. Crude potato-starch, lactose and lactulose administration was accompanied by a considerable development and a more acidic caecum $\mathrm{pH}$.

\section{TABLE 1}

Effects of various diefary carbohydrates on the development of the caecum and the main products of fermentation

\begin{tabular}{|c|c|c|c|c|c|c|}
\hline Diets & & $\mathrm{pH}$ & $\begin{array}{c}\text { Caecal } \\
\text { water* } \\
(\mathrm{ml})\end{array}$ & $\begin{array}{c}\text { Volatile } \\
\text { fatty acids } \\
\text { concentration } \\
(\mu \text { moles } / \mathrm{ml})\end{array}$ & $\begin{array}{c}\text { Volatile } \\
\text { fatty acids } \\
\text { in the caecum } \\
\text { ( } \mu \text { moles) }\end{array}$ & $\begin{array}{c}\text { Ammonia } \\
(\mu \text { moles } / \mathrm{ml})\end{array}$ \\
\hline $\begin{array}{l}\text { Wheat starch } \\
\text { Cellulose } \\
\text { Bran } \\
\text { Pectin } \\
\text { Guar gum } \\
\text { Crude potato starch } \\
\text { Lactose } \\
\text { Lactulose }\end{array}$ & $\begin{array}{r}15 \text { p. } 100 \\
15 \text { p. } 100 \\
5 \text { p. } 100 \\
5 \text { p. } 100 \\
20 \text { p. } 100 \\
20 \text { p. } 100 \\
10 \text { p. } 100\end{array}$ & $\begin{array}{l}7.42 \pm 0.08 \\
7.20 \pm 0.04 \\
6.60 \pm 0.09 \\
6.99 \pm 0.09 \\
6.74 \pm 0.05 \\
5.71 \pm 0.08 \\
5.85 \pm 0.08 \\
5.53 \pm 0.05\end{array}$ & $\begin{array}{l}1.10 \\
1.18 \\
1.64 \\
2.20 \\
2.96 \\
2.98 \\
3.50 \\
4.28\end{array}$ & $\begin{array}{r}106.2 \pm 3.0 \\
101.8 \pm 8.4 \\
120.0 \pm 5.0 \\
108.4 \pm 8.0 \\
88.4 \pm 7.3 \\
152.4 \pm 8.5 \\
130.2 \pm 7.0 \\
113.2 \pm 9.8\end{array}$ & $\begin{array}{l}116 \\
120 \\
196 \\
238 \\
262 \\
454 \\
456 \\
484\end{array}$ & $\begin{array}{l}16.0 \pm 1.0 \\
17.3 \pm 2.0 \\
10.1 \pm 0.7 \\
7.9 \pm 0.6 \\
9.1 \pm 0.8 \\
5.5 \pm 0.7 \\
2.6 \pm 0.4 \\
5.2 \pm 0.4\end{array}$ \\
\hline
\end{tabular}

Each value is the mean $\pm S E M$ for 10 rats.

* The caecal water for $200 \mathrm{~g}$ body weight was calculated as follows : 200 (total caecal weight - caecal wall weight) $\times \frac{200}{\text { body weight }} \times$ water percentage of caecal content. The VFA in the caecum (for $200 \mathrm{~g}$ body weight) is thus : VFA concentration $y . \mathrm{ml}$ of caecal water.

The VFA were the main end-products of bacterial metabolism, except for acidic fermentation, where lactic acid was present in noticeable concentrations (60 p. $100 \mathrm{~L}$, 40 p. 100 D). In rats fed a wheat-starch diet, the acetate percentage was particularly high (about 75 p. 100) with 24 p. 100 propionate. Cellulose, despite the lack of change in the $\mathrm{pH}$ and the VFA concentrations, produced an increase in the butyrate percentage. A similar increment was observed with bran, but with a higher caecal development. When the caecal $\mathrm{pH}$ was less than 6.8 , the percentage of acetate decreased. 
For moderately acidic fermentation, the substrate and the flora influenced the distribution of propionate and butyrate (bran hemicellulose favoured butyrate, while guar gum, lactose and potato-starch favoured propionate). When the $\mathrm{pH}$ was less than 5.5, the propionate decreased rapidly with the appearance of noticeable amounts of lactic and butyric acids.

TABLE 2

Composition of the main organic acids produced by caecal fermentation

\begin{tabular}{|c|c|c|c|c|c|c|}
\hline & & $\begin{array}{c}\text { Volatile } \\
\text { fatty acid } \\
\text { concentration } \\
(\mu \text { moles } / \mathrm{ml})\end{array}$ & $\begin{array}{l}\text { Acetate } \\
\text { p. } 100\end{array}$ & $\begin{array}{l}\text { Propionate } \\
\text { p. } 100\end{array}$ & $\begin{array}{c}\text { Butyrate } \\
\text { p. } 100\end{array}$ & $\begin{array}{c}\text { Lactate } \\
(\mathrm{L}+\mathrm{D}) \\
(\mu \mathrm{moles} / \mathrm{ml})\end{array}$ \\
\hline \multicolumn{7}{|c|}{ Caecal pH higher than 6.5} \\
\hline $\begin{array}{l}\text { Wheat starch } \\
\text { Cellulose } \\
\text { Bran } \\
\text { Pectin } \\
\text { Guar Gum }\end{array}$ & $\begin{array}{r}(\mathrm{pH} \mathrm{7.42)} \\
15 \text { p. } 100(\mathrm{pH} \mathrm{7.20)} \\
15 \text { p. } 100(\mathrm{pH} \mathrm{6.60)} \\
5 \text { p. } 100(\mathrm{pH} \mathrm{6.99)} \\
5 \text { p. } 100(\mathrm{pH} \mathrm{6.74)}\end{array}$ & $\begin{aligned} 106.2 & \pm 3.0 \\
101.8 & \pm 8.4 \\
120.0 & \pm 5.0 \\
108.4 & \pm 8.0 \\
88.4 & \pm 7.3\end{aligned}$ & $\begin{array}{l}74 \\
67 \\
61 \\
76 \\
63\end{array}$ & $\begin{array}{l}24 \\
22 \\
20 \\
18 \\
31\end{array}$ & $\begin{array}{r}2 \\
11 \\
19 \\
6 \\
6\end{array}$ & $\begin{array}{l}<5 \\
= \\
-\end{array}$ \\
\hline \multicolumn{7}{|c|}{ Caecal $\mathrm{pH}$ between 6.0 and 5.5} \\
\hline $\begin{array}{l}\text { Crude potato } \\
\text { Lactose } \\
\text { Lactulose }\end{array}$ & $\begin{array}{l}\text { starch } \\
20 \text { p. } 100(\mathrm{pH} 5.71) \\
20 \text { p. } 100(\mathrm{pH} 5.85) \\
10 \text { p. } 100(\mathrm{pH} \mathrm{5.53)}\end{array}$ & $\begin{array}{l}152.4 \pm 8.5 \\
130.2 \pm 7.0 \\
113.2 \pm 9.8\end{array}$ & $\begin{array}{l}64 \\
56 \\
63\end{array}$ & $\begin{array}{l}30 \\
39 \\
18\end{array}$ & $\begin{array}{r}6 \\
5 \\
19\end{array}$ & $\begin{array}{r}8.3 \pm 0.7 \\
12.0 \pm 1.3 \\
20.6 \pm 1.9\end{array}$ \\
\hline
\end{tabular}

Each value is the mean \pm SEM for 10 rats.

Urea uptake and ammonia absorption in the caecum (table 3). - Ammonia concentrations were highest with carbohydrates poorly metabolized in the caecum and when the caecal VFA pool was reduced. Ammonia was markedly decreased with carbohydrates

TABLE 3

Caecal urea uptake and ammonia absorption with various carbohydrates

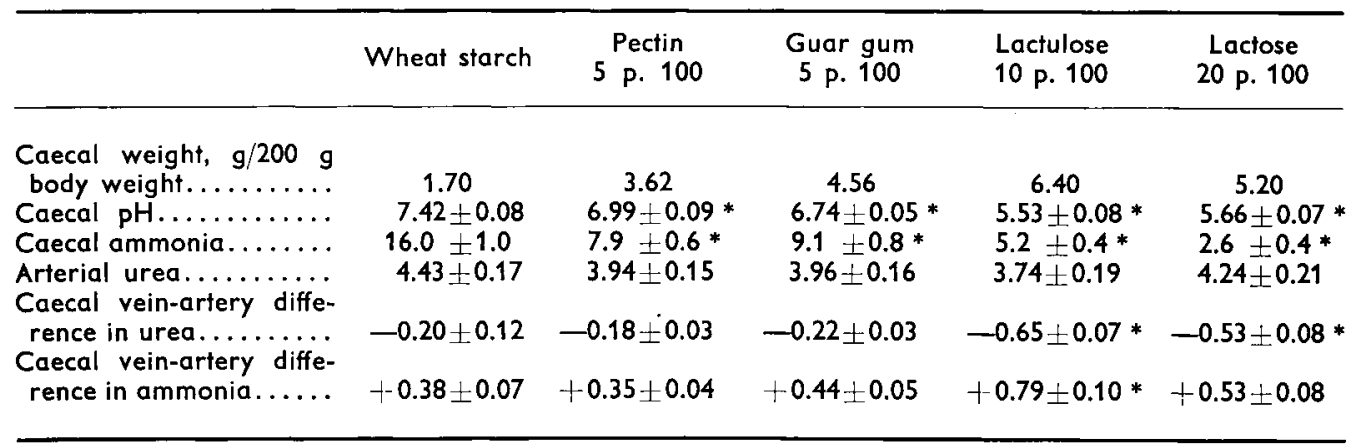

Each value is the mean $\pm S E M$ for 10 rats. Concentrations are expressed as $\mu \mathrm{moles} / \mathrm{ml}$.

* Significant differences $(P<0.05)$ for all diets vs wheat starch. 
inducing considerable caecal fermentation, even when the caecal $\mathrm{pH}$ ranged between 6.5 and 7.0. Caecal vein-artery differences in urea were proportional to uraemia and the size of the caecum (Demigné and Rémésy, 1979) ; in the present study blood urea was relatively constant and the differences in urea uplake were essentially due to changes in caecal size (probably accompanied by increased caecal blood flow). While the arterio-venous differences in urea were similar to wheat-starch with pectin and guar gum, these differences were markedly increased with lactose and lactulose, suggesting a parficularly efficient uptake of blood urea with the last two substrates. There was no clear correlation between the caecal $\mathrm{pH}$ and ammonia arterio-venous differences. Nevertheless, in wheat-starch, pectin and guar gum diets, ammonia absorption (whatever its origin) was equivalent to nitrogen reaching the caecum as blood urea. In rats fed lactose or lacfulose diets, ammonia absorption represented only 50 to 60 p. 100 of the blood urea taken up, showing a large utilization of urea nnrogen in bacterial protein synthesis. However, in these cases, the low caecal $\mathrm{pH}$ did not hinder a substantial reabsorption of ammonia, in spite of the low ammonia concentration in the caecum. Thus, readily fermentable carbohydrates reaching the caecum increased the amounts of absorbed ammonia by an enhanced uptake of urea, even if a greater fraction of nitrogen was used for bacterial growth.

Caecal vein-artery differences in VFA and minerals (table 4). - Various types of fiber have noticeable water-holding capacities, particularly gums and pectins. In addition, some acidic polysaccharides may present substantial ion-exchange abilities with possible changes in the availability of minerals for absorption in the small intestine. However, it might be that absorption of cations in the large bowel could compensate for these processes.

\section{TABLE 4}

Volatile fatty acid and mineral concentrations in arferial plasma and caecal contents and arferiovenous differences in the caecum

\begin{tabular}{lcccccc}
\hline & $\begin{array}{c}\text { Volatile } \\
\text { fatty acids }\end{array}$ & $\mathrm{Cl}$ & $\mathrm{Na}^{+}$ & $\mathrm{K}^{+}$ & $\mathrm{Ca}$ & $\mathrm{Mg}^{++}$ \\
\hline & & & & & & \\
\hline
\end{tabular}

Each value is the mean $\pm S E M$. for 10 rats. Concentrations are expressed as $\mu \mathrm{moles} / \mathrm{ml}$. 
The concentration gradients between plasma and caecal contents were very different : higher concentrations in caecal contents for VFA and to a lesser extent for $\mathrm{K}^{+}, \mathrm{Ca}^{++}$and $\mathrm{Mg}^{++}$. In contrast, caecal $\mathrm{Cl}^{-}$and $\mathrm{Na}^{+}$concentrations were substantially lower than plasma levels.

The arteriovenous differences corresponded to the observed gradients, except for $\mathrm{Na}^{+}$. Thus, VFA absorption was accompanied by a release of plasma $\mathrm{Cl}^{-}$of comparable magnitude in the caecal contents and by the absorption of various cations, $\mathrm{Na}^{+}$being absorbed along an unfavourable concentration gradient. As compared to $\mathrm{K}^{+}$and $\mathrm{Mg}^{++}$plasma concentration, their caecal arteriovenous differences were particularly striking as to the very favourable gradients for absorption. Ca ${ }^{++}$absorption, is similar to $\mathrm{Mg}^{++}$absorption but occurs along a less favourable gradient; the caecal supply seemed more important for $\mathrm{Mg}^{++}$than for $\mathrm{Ca}^{++}$in our conditions. These processes were quite similar in pectin, guar gum diets or a commercial chow diet (Rémésy, Demigné and Chartier, 1980), but there was apparently higher secretion of $\mathrm{Cl}^{-}$with pectin.

\section{Discussion.}

The development of the caecum is one of the most evident adaptive responses to the availability of fermentable carbohydrates. The effects of these carbohydrates on colonic growth is very limited as compared to caecal growth (Ryan ef al., 1979). The responsible factors are still speculative (e.g. accumulation of fermentable substances, bulk of bacterial cells, high concentrations of organic acids). The origin of caecal hypertrophy in germ-free rats is certainly very different. The retention of fluid could be related to the lack of highly diffusible anions such as chloride (Asano, 1969 ; Donowitz and Binder, 1979) or VFA, but VFA are certainly the major anions responsible for water and sodium reabsorption.

Whatever the substrates (with possible differences in caecal flora), the VFA are the main end-products of bacterial fermentation. The total VFA concentrations vary between rather narrow limits $(90$ to $150 \mathrm{mM})$, but the size of the caecum differs markedly with the diets.

In the rat, the digestibility of carbohydrates reaching the caecum (except for cell wall carbohydrates) is certainly high ( 80 p. 100 for pectin, according to Hove and King, 1979). Kim, Benevenga and Grummer (1978) estimate that approximately 50 p. 100 of lactose energy which enters the large intestine may be available to the animal as fermentation products.

In the rat, the readily fermentable carbohydrates do not decrease ammonia absorption, even with low caecal $\mathrm{pH}$ and ammonia, while in humans the favourable effect of lactulose seems well established (Bown ef al., 1974 ; Conn et al., 1977). There are several possible reasons : in humans caecal and colonic size are poorly modified, the lactulose would not markedly increase urea uptake, the acidification of colonic contents would be accompanied by a lower ureolytic activity (Vince ef al., 1973). Nevertheless, lactulose effect on ammonia utilization in bacterial proteins could certainly be exerted by other carbohydrates, such as lactose, $\alpha$-galactosides or crude potato-starch, originating from natural products. It must be stressed that protein level in the diet is important, as urea uptake by the gut depends on uraemia (Demi- 
gné and Rémésy, 1979) and glutamine hydrolysis in the small intestine is a noticeable source of ammonia (Windmueller and Spaeth, 1974).

Numerous types of fiber induce a large supply of water in the caecum; however, the strong absorption of various electrolytes in the caecum (and probably the colon) favour water absorption. The presence of VFA in the large intestine is certainly important for normal absorptive function (Argenzio, Miller and Engelhardt, 1975). In most cases, the anionic form of VFA is predominant but absorption could be effected as undissociated form, the $\mathrm{H}^{+}$ion being provided by $\mathrm{CO}_{2}$ hydratation (Argenzio ef al., 1977). However, the counter-transfer of $\mathrm{Cl}^{-}$could be related to the absorption of ionized VFA by a mechanism similar to $\mathrm{Cl}^{-} / \mathrm{HCO}_{3}^{-}$exchange. In contrast to the colon where there is absorption of $\mathrm{Cl}-\left(\mathrm{Cl} / \mathrm{HCO}_{3}^{-}\right.$exchange $)$and of $\mathrm{Na}^{+}\left(\mathrm{Na}^{+} / \mathrm{K}+\right.$ exchange) (Hawker, Mashiter and Turnberg, 1978), there is a concomitant absorption of $\mathrm{Na}^{+}$and $\mathrm{K}^{+}$in the caecum while $\mathrm{Cl}^{-}$is secreted. These results agree with the data of Leng (1978), except for the $\mathrm{Cl}^{-}$where Leng observed a net absorption with, however, unphysiological $\mathrm{Cl}^{-}$concentration in the caecal lumen. The mechanism of VFA absorption in a dissociated form is discussed by Rémésy, Demigné and Chartier (1980).

With these diets, very favourable gradients for calcium absorption occur, and a noticeable caecal absorption is observed. The impairment of calcium and magnesium absorption by dietary fibers is well documented. Mineral malabsorption is traditionally ascribed to the phytic acid content of whole grain products, but it now appears that these effects are rather related to the uronic acid confent of the fiber fractions. These changes are only short-term, and the digestive tract seems to be able in some way to adapt to the diminished availability of minerals (particularly in humans); when pectin is largely metabolized in the large intestine, there is no decrease in calcium absorption (Cummings ef al., 1979). It is suggested that the favourable effect of carbohydrate fermentation on mineral absorption may explain these results. Calcium absorption in the rat caecum may even occur with an unfavourable gradient during calcium restriction (Petith and Schedl, 1976). The favourable effect of carbohydrate fermentation on mineral absorption has already been noted for $\mathrm{Mg}$ in the monogastric large intestine (Rayssiguier and Rémésy, 1977) and for $\mathrm{Ca}$ and $\mathrm{Mg}$ in the ruminant stomach (Rayssiguier and Poncet, 1980). Absorption in the large intestine is particularly important for $\mathrm{Mg}^{++}$as absorption of that mineral in the small intestine seems limited.

Journées Ingestion-Digestion-Absorption de l'Association française de Nutrition, Paris, 15-16 novembre 1979.

Résumé. L'influence de divers glucides peu dégradés dans l'intestin grêle sur la digestion cæcale chez le rat a été étudiée. En l'absence de ce type de glucides dans la ration, il existe néanmoins une production cæcale d'AGV non négligeable. Chez le Rat, à l'exception de la cellulose, les glucides étudiés (son, pectine, gomme, amidon cru de pomme de terre, lactose, lactulose) augmentent la taille du cæcum et le pool cæcal d'AGV. Les glucides parvenant dans le cæcum augmentent l'absorption d'ammoniaque par accroissement de la captation d'urée sanguine, bien qu'une plus grande proportion de l'azote uréique soit utilisée dans les synthèses protéiques bactériennes. Par différences artérioveineuses au niveau du cæcum, il est possible de mettre en évidence une forte absorption d'électrolytes. 
L'absorption des AGV semble couplée à une sécrétion de $\mathrm{Cl}^{-}$et à l'absorption des cations majeurs, seul le $\mathrm{Na}^{+}$éfant absorbé contre un gradient de concentration plasma/contenu cæcal défavorable.

\section{Références}

ARGENZIO R. A., MILLER N., von ENGELHARDT W., 1975. Effect of volatile fatty acids on water and ion absorption from the goat colon. Am. J. Physiol., 229, 997-1002.

ARGENZIO R. A., SOUTHWORTH M., LOWE J. E., STEVENS C. E., 1977. Interrelationship of Na, $\mathrm{HCO}_{3}$ and volatile fatty acid transport by equine large intestine. Am. J. Physiol., 233, E469E478.

ASANO T., 1969. Modification of cecal size in germ-free rats by long-ferm feeding of anion exchange resin. Am. J. Physiol., 217, 911-918.

BAILEY R. W., CHESSON A., MONRO J., 1978. Plant cell wall fractionation and structural analysis. Am. J. clin. Nutr., 31, 577-581.

BERGMEYER H. U., 1974. In Methods of Enzymotic Analysis, pp. 1464, 1492, 1794 and 1802. Acad. Press, London.

BOWN R. L., GIBSON J. A., SLADEN G. E., HICKS B., DAWSON A. M., 1974. Effects of lactulose and other laxatives on ileal and colonic $\mathrm{pH}$ as measured by radiotelemetry device. Gut, 15, 999-1004.

CONN H. O., LEEVY C. M., VLAHCEVIC Z. R., RODGERS J. B., MADDREY W. C., SEEFF L., LEVY L. L., 1977. Comparison of lactulose and neomycin in the treatment of chronic portalsystem encephalopathy. Gostroenterology, 72, 573-582.

CUMMINGS J. H., SOUTHGATE D. A. T., BRANCH W. J., WIGGINS H. S., 1979. The digestion of pectin in the human gut and its effect on calcium absorption and large bowel function. Br. J. Nutr., 41, 477.

DEMIGNÉ C., RÉMÉSY C., 1979. Urea cycling and ammonia absorption in vivo in the digestive tract of the rat. Ann. Biol. anim. Bioch. Biophys., 19, 929-935.

DONOWITZ M., BINDER H. J., 1979. Mechanism of fluid and electrolyte secretion in the germ-free rat cecum. Am. J. Dig. Dis., 24, 551-559.

HAWKER P. C., MASHITER K. E., TURNBERG L. A., 1978. Mechanisms of transport of $\mathrm{Na}, \mathrm{Cl}$ and K in the human colon. Gastroenterology, 74, 1241-1247.

HOVE E. L., KING S., 1979. Effects of pectin and cellulose on growth, feed efficiency and protein utilization, and their contribution to energy requirement and caecal VFA in rats. J. Nutr., 109, 1274-1278.

KEYS J. E., VAN SOEST P. J., YOUNG E. P., 1969. Comparative study of the digestibility of forage cellulose and hemicellulose in ruminants and non-ruminants. J. Anim. Sci., 29, 11-15.

KIM K., BENEVENGA N. J., GRUMMER R. H., 1978. Estimation of the fraction of the lactose in a high lactose diet available for fermentation in the caecum and colon of the rat. J. Nutr., 108, 79-89.

KNUTSON R. S., FRANCIS J. L., HALL B. H., HEISINGER J. F., 1977. Ammonia and urea distribution and urease activity in the gastrointestinal tract of rabbit (Oryctolagus and Sylvilagus). Comp. Biochem. Physiol., 58, 151-154.

LENG E., 1978. Absorption of inorganic ions and volatile fatty acids in the rabbit caecum. Br. J. Nutr., 40, 509-519.

MCNEIL N. I., CUMMINGS J. H., JAMES W. P. T., 1978. Short-chain fatty acid absorption by the human large intestine. Gut, 19, 819-822.

PETITH M. M., SCHEDL H. P., 1976. Intestinal adaptation to dietary calcium restriction : In vivo caecal and colonic calcium transport in the rat. Gastroenterology, 71,1039-1042.

RAYSSIGUIER Y., RÉMÉSY C., 1977. Magnesium absorption in the caecum of rats related to volatile fatty acid production. Ann. Rech. vét., 8, 105-110.

RAYSSIGUIER Y., PONCET C., 1980. Effect of lactose on absorption of magnesium and calcium in the stomach of sheep. J. Anim. Sci. (in press).

RÉMÉSY C., DEMIGNÉ C., 1974. Determination of volatile fatty acids in plasma after ethanolic extraction. Biochem. J., 141, 85-91.

RÉMÉSY C., DEMIGNÉ C., 1976. Partition and absorption of volatile fatty acids in the alimentary canal of the rat. Ann. Rech. vét., 7, 39-55. 
RÉMÉSY C., DEMIGNÉ C., CHARTIER F., 1980. Origin and utilization of volatile fatty acids in the rat. Reprod. Nutr. Dévelop., 20, 1339-1349.

RYAN G. P., DUDRICK S. J., COPELAND E. M., JOHNSON L. R., 1979. Effects of various diets on colonic growth in rats. Gastroenterology, 77, 658-663.

TROWELL H., 1978. The development of the concept of dietary fiber in human nutrition. Am. J. clin. Nutr., 31, 53-511.

VINCE A., DAWSON A. M., PARK N., O'GRADY F., 1973. Ammonia production by intestinal bacteria. Gut, 14, 171-177.

VINCE A., KILLINGLEY M., WRONG O. M., 1978. Effect of lactulose on ammonia production in a fecal incubation system. Gastroenterology, 74, 544-549.

WINDMUELLER H. G., SPAETH A. E., 1974. Uptake and metabolism of plasma glutamine by the small intestine. J. biol. Chem., 249, 5070-5079.

YANG M. G., MANOHARAN K., MICKELSEN O., 1970. Nutritional contribution of volatile fatty acids from the caecum of rats. J. Nutr., 100, 545-550. 